\title{
Evaluation of some Heavy Metals Loading in Dust Fall of Three Universities Motor Parks in Western Nigeria
}

\author{
*1NWOSU, FO; ${ }^{2}$ A. M. O. ABDUL RAHEEM; ${ }^{3} \mathrm{Z}$. SHEHU \\ Department of Industrial Chemistry, Faculty of Physical Sciences, University of Ilorin \\ P.M. B. 1515, Ilorin, Nigeria \\ Department of Chemistry, Faculty of Physical Sciences, University of Ilorin, P.M. B. 1515, Ilorin, Nigeria \\ ${ }^{3}$ Deparment of Chemistry, Gombe State University, P.M.B. 127, Gombe, Gombe state, Nigeria \\ *Corresponding Author: F. O. Nwosu: E-mail:f.o.nwosu@gmail.com
}

\begin{abstract}
The high density of vehicles that run to and fro University campus to town has become of great concern for assessment of health status of the ambient air around the Universities motor parks. Moreover, some of the University's parks are unpaved while the paved ones are old and unmaintained. Dust fall samples in parks of Universities of Ilorin, Ibadan and Kwara State University were collected for five months spanning from 1st November 2014 to 31st March, 2015 using open bucket sampler based on ASTM D 1739 of 1998 (2010). A $0.1 \mathrm{~g}$ of dust sample was digested with $20 \mathrm{ml}$ of $\mathrm{HNO}_{3}, \mathrm{HClO}_{4}$ and $\mathrm{HF}$ in ratio of (3:2:1) respectively and heavy metals $(\mathrm{Mn}, \mathrm{Cu}, \mathrm{Zn}, \mathrm{Cd}, \mathrm{Pb}$, and $\mathrm{Ni}$ ) were analysed using atomic absorption spectrophotometer (Buck Scientific model 210 VGP). Results of heavy metal concentrations showed decrease in the following order: $1479.75,1255.68,241.50,128.00,85.25$, and $9.63 \mathrm{mg} / \mathrm{kg}$ for $\mathrm{Mn}, \mathrm{Zn}, \mathrm{Pb}, \mathrm{Ni}, \mathrm{Cu}$ and $\mathrm{Cd}$ respectively for University of Ibadan. The decreased in concentrations of heavy metals obtained for University of Ilorin motor park dust-fall were found to be 1145.75, 797.75, 219.63, 133.51, 58.25 and $23.13 \mathrm{mg} / \mathrm{kg}$ for $\mathrm{Mn}, \mathrm{Zn}, \mathrm{Pb}, \mathrm{Ni}, \mathrm{Cu}$ and $\mathrm{Cd}$ respectively. For Kwara State University, decrease in the following order: 778.5, 323.88, 259.38, 101.38, 34.38, and $4.63 \mathrm{mg} / \mathrm{kg}$ for $\mathrm{Mn}, \mathrm{Zn}, \mathrm{Pb}, \mathrm{Ni}, \mathrm{Cu}$ and $\mathrm{Cd}$ respectively were obtained. Generally for the three sites used, the heavy metal concentrations decreased in the following order: $\mathrm{Mn}>\mathrm{Zn}>\mathrm{Pb}>\mathrm{Ni}>\mathrm{Cu}>\mathrm{Cd}$. This implies that dust-fall in the parks are heavily loaded with some heavy metals that are of concentrations above Romania standard threshold limit for $\mathrm{Cd}$ and $\mathrm{Pb}$ while concentration values obtained for Ni are higher than US- EPA values $(75 \mathrm{mg} / \mathrm{kg}$ ). The regulatory agent or management should ensure that the roads are paved and there should be intermittent wetting of the roads with water. (OJASEM
\end{abstract}

http://dx.doi.org/10.4314/jasem.v20i2.13

KEYWORDS: Dust Fall; Heavy Metals; University Motor Parks

Introduction

Particulate matters are complex heterogeneous mixture of solid and liquid components such as those from power plants and industries, gas flaring, motor vehicles and natural source elements such as dust (Yahi et al., 2014). Dust can be defined as matter or particulate in the form of fine powder, lying on the ground or on the surface of objects or blown about by the wind (Adekola and Dosumu, 2001). Dust contains pollutants such as polycyclic aromatic compounds, biological material and heavy metals. They are kept suspended in air or transported from sources by wind and can travel long distances across regions, and continents transferring contaminants to ecosystems (Adriaenssens, 2011). Dust enters the nose and mouth during breathing and is therefore available for deposition in the respiratory tract which increases the potential health effects of occupants in any environment. The potential health effects posed by heavy metals include organ damage, blindness, deafness, breathing, sex problems and death (Mnisi and Moja, 2013). Therefore, assessing the extent of dust composition in terms of heavy metals in these parks will provide possible information on hazards it may pose.

The choice of the sampling sites was due to the fact that the motor parks are more prone to anthropogenic pollution due to high traffic volume and commercial activities on which the extent of heavy metal composition might depends, whether the parks are paved or unpaved. Therefore, this study is aimed at comparison of concentrations of some heavy metals $(\mathrm{Mn}, \mathrm{Cu}, \mathrm{Zn}, \mathrm{Cd}, \mathrm{Pb}$ and $\mathrm{Ni}$ ) in the dust-fall from the University of Ilorin, Kwara State University and University of Ibadan Motor Parks in Nigeria.

\section{MATERIALS AND METHOD}

The study area: Three monitoring stations; University of Ilorin, Kwara State University and University of Ibadan motor parks were chosen for this study. Both University of Ilorin, Ilorin and Kwara State University, Ilorin are located in Kwara State, Nigeria and lie on longitude $8^{\circ} 30^{\prime} \mathrm{N}$ and latitude $4^{\circ} 40^{\prime} \mathrm{E}$ while University of Ibadan is located in Ibadan metropolis, Oyo State, Nigeria and it lies on longitude $7^{\circ} 22^{\prime} \mathrm{N}$ and 
latitude $3^{\circ} 58^{\prime}$ E. Figure 1 describes street map of Ilorin showing University of Ilorin, Ilorin and Kwara State University, Molete, Ilorin while Figure 2 depicts map of Ibadan metropolis indicating location of University of Ibadan, Ibadan, Nigeria.

Collection of dust-fall: The samples were collected for five months from 1st November, 2014 to 31st March, 2015. The ambient dust (particulate matter) was collected using single open bucket sampler in which the mass concentration of the particulate matter (settled dust) is given in $\mathrm{mg} \mathrm{m}^{-2} \mathrm{day}^{-1}$. Single open bucket sampler is based on the American Standard Test Method (ASTM) D1739 of 1998 (2010) and is shown in Figure 3. The bucket was placed on a rigid stand comprising of a ring supported by four stabilizing bars above the base plate. This serves to prevent contamination of the sample by perching birds. A net insect screen was also placed over the open bucket to prevent insects' contamination. The base plate was connected to a $2 \mathrm{~m}$ long steel pole which was buried to a depth of approximately $0.5 \mathrm{~m}$.

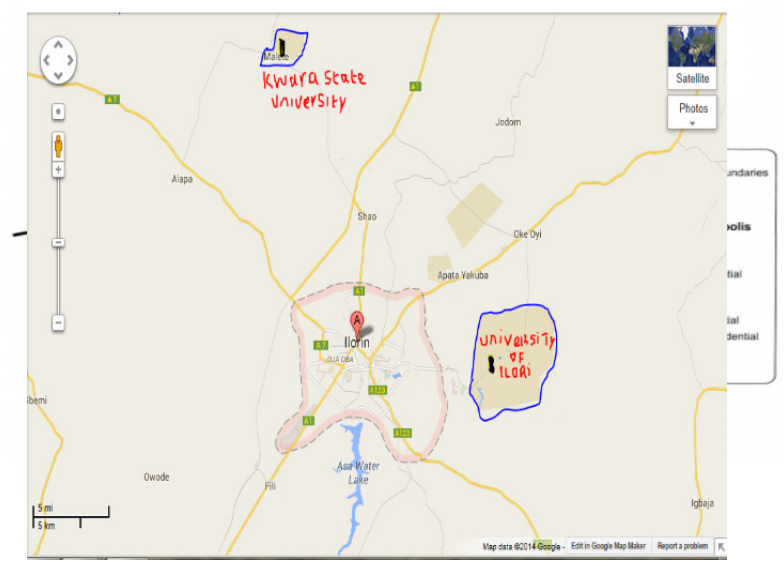

Fig. 1: Street map of Ilorin showing University of Ilorin and Kwara State University

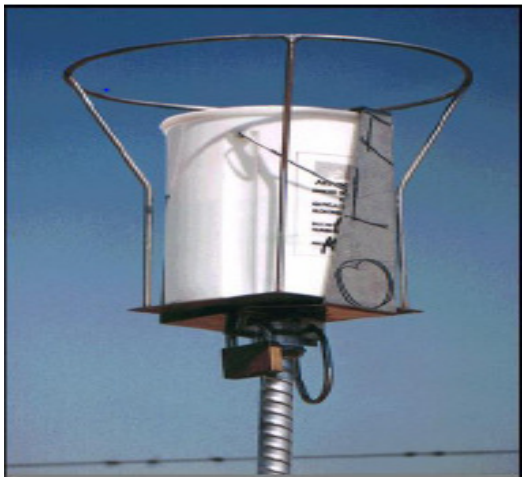

Fig. 3: Single open bucket sampler (ASTM D1739, 2010)

The method did not have a wind shield around the bucket so that both coarse and fine precipitating dust samples could be collected irrespective of the wind situation. Settling dust material was collected in $20 \mathrm{~L}$ cylindrical plastic buckets half filled with distilled water (10 L). The height (h), radius (r) and the area (A) of the bucket (bottom) are $0.342 \mathrm{~m}, 0.138 \mathrm{~m}$ and 0.060 $\mathrm{m}^{2}$ respectively (Figure 3 ). Exposed buckets were replaced after 30 days of sampling period and transported to the laboratory for further treatment and analysis. Water - dust sample mixtures were separately filtered through pre-weighed $0.47 \mathrm{~mm}$ Whatman filter papers under low pressure. The samples were air dried in partially open petri dishes in a "dust free laboratory". After drying, gravimetric analysis was conducted to determine the insoluble fraction which is based on dust deposition rate equation:

$$
C u=M f-\frac{M b}{A t} \quad 1
$$

where $\mathrm{Cu}$ indicates dust deposition rate $\left(\mathrm{mg} \mathrm{m}^{-2} \mathrm{day}^{-1}\right)$, Mf is weight of loaded filter (mg), Mb is weight of blank filter paper (mg), A represent Area of the bucket $\left(\mathrm{m}^{2}\right)$ and $\mathrm{t}$ is Sample duration (days).

Digestion and analysis of sample
A $0.1 \mathrm{~g}$ of dust sample was digested with $20 \mathrm{ml}$ of $\mathrm{HNO}_{3}, \mathrm{HClO}_{4}$ and $\mathrm{HF}$ in ratio of (3:2:1) respectively and heated to near dryness. The residue was dissolved in $2 \mathrm{ml}$ concentrated $\mathrm{HCl}$ and filtered. The resulting solution was diluted to $12.5 \mathrm{~mL}$ with deionized water and heavy metals $(\mathrm{Mn}, \mathrm{Cu}, \mathrm{Zn}, \mathrm{Cd}, \mathrm{Pb}$, and $\mathrm{Ni}$ ) were analysed using air-acetylene flame atomic absorption spectrometry (AAS, Buck Scientific model, 210VGP) (Matthews et al., 2012). Blank studies were also carried out. Prior to analysis, all glassware were soaked for 24 hours in dilute nitric acid solution, rinsed with deionised water and dried in oven before use.

\section{RESULTS AND DISCUSSION}

Table 1 revealed the average dust fall depositions of five consecutive months of dry season (1st November, 2014 to 31st March, 2015) to be 1122.2, 627.7 and $316.3 \mathrm{mg} \mathrm{m}^{-2} \mathrm{day}^{-1}$ for University of Ilorin (Un), Kwara State University (Kw) and University of Ibadan (UI) sites respectively while their average traffic count was found to be $300,103.2$ and 273.4 day $^{-1}$. It could be observed that traffic count at Un was almost three times that of Kw while that of UI was greater than that of Kw. This has reflected in the dust fall deposition as the higher the traffic count, the larger the dust fall deposition (Table 1). The lowest Dust fall of $949.5 \mathrm{mg}$ 
$\mathrm{m}^{-2} \mathrm{day}^{-1}$ was obtained in the month of March, 2015 while the highest Dust fall was obtained in the month of January, 2015 (Table1). The increase in the amount of monthly average dust fall for the month of January was due to increased number of vehicles that entered the motor parks which was about 500 from 6 am to 6 $\mathrm{pm}$ in a day. Similar observation has been reported by
Beg et al., (1987), Khan et al., (2002), Norela et al., (2009), Khan et al., (2013), Malokootia et al., (2013) and Tyagi et al., (2014).

Table 2 presents monthly mean concentrations as well as total mean of some heavy metals loaded in the dust that fell at Un Motor Park.

Table 1: Comparison of dust deposition of three universities' parks

\begin{tabular}{|c|c|c|c|c|c|c|}
\hline \multirow[t]{2}{*}{ Months/sites } & \multicolumn{2}{|l|}{ University of Ilorin } & \multicolumn{2}{|c|}{ Kwara state University } & \multicolumn{2}{|c|}{ University of Ibadan } \\
\hline & $\begin{array}{l}\text { Dust fall }\left(\mathrm{mg} \mathrm{m}^{-}\right. \\
\left.{ }^{2} \mathrm{day}^{-1}\right)\end{array}$ & $\begin{array}{l}\text { Traffic } \\
\text { count } \\
\left(\text { day }^{-1}\right)\end{array}$ & $\begin{array}{c}\text { Dust fall } \\
\left(\mathrm{mgm}^{-2} \mathrm{day}^{-1}\right)\end{array}$ & $\begin{array}{l}\text { Traffic } \\
\text { count }\left(\text { day }^{-1}\right)\end{array}$ & $\begin{array}{c}\text { Dust fall } \\
\left(\mathrm{mg} \mathrm{m}^{-2} \mathrm{day}^{-1}\right)\end{array}$ & $\begin{array}{l}\text { Traffic } \\
\text { count }\left(\text { day }^{-1}\right)\end{array}$ \\
\hline November, 2014 & $1119.4 \pm 71$ & 333 & $442.7 \pm 4$ & 83 & $214.4 \pm 4$ & 267 \\
\hline December, 2014 & $1044.2 \pm 59$ & 317 & $150.4 \pm 8$ & 33 & $97.5 \pm 4$ & 67 \\
\hline January, 2014 & $1517.6 \pm 51$ & 500 & $598.7 \pm 4$ & 100 & $320.2 \pm 20$ & 333 \\
\hline February, 2015 & $980.1 \pm 71$ & 200 & $1211.4 \pm 82$ & 167 & $785.2 \pm 47$ & 533 \\
\hline March, 2015 & $949.5 \pm 35$ & 150 & $735.1 \pm 24$ & 133 & $164.3 \pm 4$ & 167 \\
\hline Average & $1122.2 \pm 57$ & 300 & $627.7 \pm 24.4$ & 103.2 & $316.3 \pm 15.8$ & 273.4 \\
\hline
\end{tabular}

Generally, a decrease of total mean of the heavy metals for the five months of study has been found to be in the following order: $1145.75,797.75,219.63,133.51,58.25$ and $23.13 \mathrm{mg} / \mathrm{kg}$ for $\mathrm{Mn}, \mathrm{Zn}, \mathrm{Pb}, \mathrm{Ni}, \mathrm{Cu}$ and $\mathrm{Cd}$ respectively. The heavy metal with highest total mean concentration is $\mathrm{Mn}(1145.45 \mathrm{mg} / \mathrm{kg}) \mathrm{while}$ the lowest is $\mathrm{Cd}(23.13 \mathrm{mg} / \mathrm{kg})$. Their monthly variations indicated that the concentrations of the heavy metals varied within each month.

Table 2: Monthly mean concentration of heavy metals in the Dust fall at University of Ilorin

\begin{tabular}{cccllll}
\hline & \multicolumn{7}{c}{ Mean concentration $(\mathbf{m g} / \mathbf{k g})$} \\
\cline { 2 - 7 } UnN & \multicolumn{1}{c}{$\mathrm{Mn}$} & $\mathrm{Cu}$ & $\mathrm{Zn}$ & $\mathrm{Cd}$ & $\mathrm{Pb}$ & $\mathrm{Ni}$ \\
UnD & $438.75 \pm 8.84$ & $31.88 \pm 0.88$ & $323.13 \pm 0.88$ & $5.63 \pm 0.88$ & $105.63 \pm 0.88$ & $119.38 \pm 0.88$ \\
UnJ & $1286.88 \pm 0.88$ & $63.13 \pm 0.88$ & $1429.38 \pm 2.65$ & $0 \pm 0.00$ & $356.25 \pm 8.84$ & $152.50 \pm 1.77$ \\
UnF & $1878.13 \pm 0.88$ & $75.63 \pm 0.88$ & $458.13 \pm 0.88$ & $8.13 \pm 0.88$ & $66.25 \pm 1.77$ & $113.13 \pm 0.88$ \\
UnM & $1881.25 \pm 1.77$ & $76.88 \pm 0.88$ & $1326.25 \pm 1.77$ & $95.63 \pm 0.88$ & $218.13 \pm 0.88$ & $91.88 \pm 0.88$ \\
Total & $1145.75 \pm 78$ & $58.25 \pm 20$ & $797.75 \pm 53$ & $23.13 \pm 40$ & $219.63 \pm 13$ & $133.50 \pm 39$ \\
mean & & & & & & \\
\hline
\end{tabular}

$( \pm)$ means standard Deviation, N=November, D=December, January, February and March

From Table 2, the month of March, 2015 contained dust fall loaded with highest concentration (1881.25 $\mathrm{mg} / \mathrm{Kg}$ ) of Mn while the dust of month of November, 2014 exhibited the least concentration $(243.75 \mathrm{mg} / \mathrm{Kg})$ of Mn. Thus, the concentrations of $\mathrm{Mn}$ in the dust obtained within the five months period are in the increasing order of: $\mathrm{UnN}<\mathrm{UnD}<$ UnJ $<$ UnF $<$ UnM. It has been observed that the concentration of $\mathrm{Mn}$ in December 2014 was about twice its value obtained in November 2014. However, the Mn concentration loaded in the dust obtained for January 2015 collected was found to be about five times of that of November 2014. The months of February and March 2015 experienced height of anthropogenic activities (Table 2 ). The volume of vehicle that ran to and fro on the unpaved park of Un was highest for month of January, 2015 compared to other months (Table 1). The alert threshold limit of Mn concentration in dust (top soil) for Romania standard is $1500 \mathrm{mg} / \mathrm{kg}$ and is found close to that of UI $(1479.75 \mathrm{mg} / \mathrm{kg})$.
More so, the concentrations of $\mathrm{Cu}, \mathrm{Zn}, \mathrm{Cd}, \mathrm{Pb}$ and $\mathrm{Ni}$ fell within ranges of $31.88-76.88 ; 323.13$ - 1429.38; 0.00 - 95.63; 66.25 - 356.25; and 91.88 - 190.63 $\mathrm{mg} / \mathrm{kg}$ respectively (Table 2). Table 2 described the monthly variation of $\mathrm{Cu}$ and $\mathrm{Pb}$ with highest values $(76.88,95.63 \mathrm{mg} / \mathrm{kg})$ obtained in the month of March, 2015 which was the onset of rain during which a lot of wind blew. The Romania threshold limit for , $\mathrm{Zn}, \mathrm{Cd}$ and, $\mathrm{Pb}$ are reported as $300,3.0$ and $50 \mathrm{mg} / \mathrm{kg}$ respectively while US -EPA limit for $\mathrm{Ni}(75 \mathrm{mg} / \mathrm{kg})$ was lower than values obtained for Un $(133.50 \mathrm{mg} / \mathrm{kg})$ , $\mathrm{Kw}(101.38 \mathrm{mg} / \mathrm{kg})$ and UI (128.00 mg/kg) respectively. Therefore, the dust at Un unpaved park is loaded with the investigated heavy metals and as such are detrimental to health status of users of the park.

The monthly mean concentrations of some heavy metals ( $\mathrm{Mn}, \mathrm{Zn}, \mathrm{Pb}, \mathrm{Ni}, \mathrm{Cu}$ and $\mathrm{Cd}$ ) at Kwara State University $(\mathrm{Kw})$ are shown in Table 3 which indicated that the concentrations of the heavy metals varied within each month. Generally, total mean concentrations of heavy metals decreased in the 
following order: 778.5, 323.88, 259.38, 101.38, 34.38 and $4.63 \mathrm{mg} / \mathrm{kg}$ for $\mathrm{Mn}, \mathrm{Zn}, \mathrm{Pb}, \mathrm{Ni}, \mathrm{Cu}$ and $\mathrm{Cd}$ respectively during the months under investigation. It was observed that Mn concentrations was highest and followed by $\mathrm{Zn}$ within each month. However, concentrations of $\mathrm{Cd}$ were found to be low in each month but values were greater than Romania standard threshold limit $(3.0 \mathrm{mg} / \mathrm{kg}$ ) for Cd in soils (US -EPA, 2005)

Table 3: Monthly mean concentration of heavy metals in the Dust fall at Kwara State University, Ilorin

\begin{tabular}{lllllll}
\hline & \multicolumn{7}{c}{ Mean concentrations $(\mathbf{m g} / \mathbf{k g})$} \\
\cline { 2 - 7 } KwN & $\mathrm{Mn}$ & $\mathrm{Cu}$ & $\mathrm{Zn}$ & $\mathrm{Cd}$ & $\mathrm{Pb}$ & $\mathrm{Ni}$ \\
KwD & $713.13 \pm 0.88$ & $26.88 \pm 0.88$ & $215.00 \pm 3.54$ & $5 \pm 0.00$ & $125.63 \pm 0.88$ & $113.13 \pm 0.88$ \\
KwJ & $643.75 \pm 8.84$ & $29.38 \pm 0.88$ & $350.63 \pm 0.88$ & $0.0 \pm 0.00$ & $375.63 \pm 0.88$ & $127.50 \pm 1.77$ \\
KwF & $468.75 \pm 8.84$ & $23.13 \pm 0.88$ & $275.63 \pm 0.88$ & $5 \pm 0.00$ & $303.13 \pm 4.42$ & $50.63 \pm 0.88$ \\
KwM & $1378.75 \pm 5.30$ & $64.38 \pm 0.88$ & $376.88 \pm 0.88$ & $6.25 \pm 0.00$ & $216.88 \pm 2.65$ & $100.63 \pm 0.88$ \\
$\begin{array}{c}\text { Total } \\
\text { mean }\end{array}$ & $778.50 \pm 354$ & $34.38 \pm 17$ & $323.88 \pm 77$ & $4.63 \pm 3$ & $259.38 \pm 94$ & $101.38 \pm 30$ \\
\hline
\end{tabular}

$( \pm)$ means standard Deviation, N=November, D=December, January, February, and March for Kwara State University $(\mathrm{Kw})$

The ranges of values of $613.13-1378.75,23.13-$ $64.38,215.0-401.25,5.0-6.87$ and $50.63-127.5$ $\mathrm{mg} / \mathrm{kg}$ obtained for $\mathrm{Kw}$ motor park dust loaded with $\mathrm{Mn}, \mathrm{Cu}, \mathrm{Zn} \mathrm{Cd}$ and $\mathrm{Ni}$ respectively were lower than their corresponding values from Un motor park (Table $3)$.

The monthly mean concentrations and variations of heavy metals at University of Ibadan (UI) are shown in Table 4 which also indicated that the concentrations of the heavy metals varied within each month. Generally, total mean concentrations of heavy metals decreased in the following order: 1479.75, 1255.68,
$241.50,128.00,85.25$, and $9.63 \mathrm{mg} / \mathrm{kg}$ for $\mathrm{Mn}, \mathrm{Zn}, \mathrm{Pb}$, $\mathrm{Ni}, \mathrm{Cu}$ and $\mathrm{Cd}$ respectively.

The UI motor park dust loaded with certain heavy metals revealed that $\mathrm{Mn}, \mathrm{Zn}, \mathrm{Pb}, \mathrm{Ni}, \mathrm{Cu}$ and $\mathrm{Cd}$ contained ranges of concentration values of 393.13 $2126.25,283.75$ - 3814.38, 142.5 - 400.63, 87.5 195.63, $28.75-197.5$ and $1.25-20.0 \mathrm{mg} / \mathrm{kg}$ respectively for the five months period of investigation (Table 4). Their monthly variations are also indicated that concentrations of the various heavy metals were obtained for each month

Table 4: Monthly mean concentration of heavy metals in the Dust fall at university of Ibadan

\begin{tabular}{lllllll}
\hline & \multicolumn{6}{l}{ Mean concentration $(\mathbf{m g} / \mathbf{k g})$ and Standard Deviation $( \pm)$} \\
\cline { 2 - 7 } & $\mathrm{Mn}$ & $\mathrm{Cu}$ & $\mathrm{Zn}$ & $\mathrm{Cd}$ & $\mathrm{Pb}$ & $\mathrm{Ni}$ \\
UIN & $393.13 \pm 7.95$ & $28.75 \pm 3.54$ & $283.75 \pm 1.77$ & $20.0 \pm 0.00$ & $142.5 \pm 1.77$ & $100.63 \pm 0.88$ \\
UID & $1250.63 \pm 0.88$ & $33.13 \pm 0.88$ & $306.88 \pm 2.65$ & $5.0 \pm 0.00$ & $400.63 \pm 0.88$ & $87.5 \pm 0.00$ \\
UIJ & $2126.25 \pm 1.77$ & $41.25 \pm 1.77$ & $592.5 \pm 3.54$ & $1.25 \pm 0.00$ & $375.63 \pm 0.88$ & $195.63 \pm 0.88$ \\
UIF & $1875.63 \pm 0.88$ & $125.63 \pm 0.88$ & $3814.38 \pm 2.65$ & $7.5 \pm 0.00$ & $144.37 \pm 0.88$ & $128.13 \pm 0.88$ \\
UIM & $1753.13 \pm 4.42$ & $197.5 \pm 1.77$ & $1280.63 \pm 0.88$ & $14.38 \pm 0.88$ & $144.38 \pm 0.88$ & $128.13 \pm 0.88$ \\
& $1479.75 \pm 69$ & $85.25 \pm 74$ & $1255.63 \pm 15$ & $9.63 \pm 8$ & $241.50 \pm 13$ & $128.00 \pm 41$ \\
Total & & & & & & \\
mean & & & & & & \\
\hline
\end{tabular}

( \pm ) means standard Deviation, N=November, D=December, January, February, and March

Comparing the three sites and using total mean concentrations, the increasing order of pollution by each of the heavy metals loaded in the dust could be given as follows (Tables $2-4$ ): For $\mathrm{Mn}: \mathrm{Kw}<\mathrm{Un}<$ UI; $\mathrm{Cu}: \mathrm{Kw}<\mathrm{Un}<\mathrm{UI}$; Zn: Kw < Un < UI; Cd: Kw $<$ $\mathrm{UI}<\mathrm{Un} ; \quad \mathrm{Pb}: \mathrm{Un}<\mathrm{UI}<\mathrm{Kw}$ and $\mathrm{Ni}: \mathrm{Kw}<\mathrm{UI}<\mathrm{Un}$. It can be observed that UI site had the highest total mean concentration of $\mathrm{Mn}, \mathrm{Cu}$ and $\mathrm{Zn}$; and was followed by Un site while Kw site exhibited the lowest concentrations of these metals. The high concentrations of $\mathrm{Mn}, \mathrm{Cu}$, and $\mathrm{Zn}$ at UI Park could be attributed to engine part wear during the five months period. The high value of $\mathrm{Mn}$ concentration might cause colouration of wells or streams when leached into water bodies. The high $\mathrm{Cu}$ content could also cause bad odour to water bodies in this vicinity.

However, in terms of dust fall $\left(\mathrm{mg} \mathrm{m}^{-2} \mathrm{day}^{-1}\right)$, UI exhibited the lowest while Un exhibited the highest. This could be attributed to the paved UI Park as opposed to unpaved Un Park despite that Un had the highest traffic count 300 day $^{-1}$ followed by 273 day $^{-1}$ for UI and $103 \mathrm{day}^{-1}$ for Kw. Therefore, the users of Un are likely to be prone to breathing difficulty and the park might be unbearable for asthmatic patients. 
The results of present study were also compared with other recent studies obtained from different countries over the World as in Table 5. The deposition of $\mathrm{Cu}$ and $\mathrm{Pb}$ in Central India were found to be higher than the current study while $\mathrm{Zn}$ was in the same range (Ghosh, 2014). Another study in West India, Pakistan and (Assiut) Egypt were found to have deposition of $\mathrm{Mn}$, $\mathrm{Cu}, \mathrm{Zn}, \mathrm{Cd}$, and $\mathrm{Pb}$ in the same range with the current study (Meena et al., 2014, Khan et al., 2013 and Mohamed et al., 2013). However, the deposition of $\mathrm{Mn}, \mathrm{Cu}, \mathrm{Zn}, \mathrm{Pb}$ and $\mathrm{Ni}$ in Vanderbijlpark, South Africa were found to be higher than the current study (Mnisi and Moja, 2013). Concentrations of Mn, $\mathrm{Zn}, \mathrm{Cd}$ and $\mathrm{Ni}$ reported by some researchers were found to be in the same range with the present study (Feng et al., 2012 and Krolak, 2000).

Table 5: Comparison of mean concentrations of heavy metal in the Dust fall of the present with other Study

\begin{tabular}{|c|c|c|c|c|c|c|}
\hline \multirow[b]{2}{*}{ This studv: } & \multicolumn{5}{|c|}{ Mean Concentration of heavy metals in Dust fall (mg/kg) } & \multirow[b]{2}{*}{$\mathrm{Ni}$} \\
\hline & Mn & $\mathrm{Cu}$ & $\mathrm{Zn}$ & $\mathrm{Cd}$ & $\mathrm{Pb}$ & \\
\hline Un & 1145.75 & 58.25 & 797.75 & 23.13 & 219.63 & 133.50 \\
\hline Kw & 778.50 & 34.38 & 323.88 & 4.63 & 259.38 & 101.38 \\
\hline UI & 1479.75 & 85.25 & 1255.63 & 9.63 & 241.50 & 128 \\
\hline $\begin{array}{l}\text { Ghosh, } 2014 \\
\text { Central India }\end{array}$ & nd & 157.53 & 533.79 & nd & 830.90 & nd \\
\hline $\begin{array}{l}\text { Meena et al., } 2014 \\
\text { West India }\end{array}$ & nd & 49.80 & 288.16 & 8.46 & 160.98 & nd \\
\hline $\begin{array}{l}\text { Khan et al., } 2013 \\
\text { Pakistan }\end{array}$ & 11900 & 3700 & 9900 & nd & 4600 & 2400 \\
\hline $\begin{array}{l}\text { Mnisi and Moja, } 2013 \\
\text { Vanderbijlpark, South Africa }\end{array}$ & $1155-4505$ & $390-1505$ & $560-2935$ & $500-1460$ & $250-1170$ & $350-1820$ \\
\hline $\begin{array}{l}\text { Mohamed } \text { et al., } 2013 \\
\text { Assiu, Egypt }\end{array}$ & nd & 26.46 & 235.00 & 4.53 & 22.33 & $\mathrm{Nd}$ \\
\hline $\begin{array}{l}\text { Feng et al, } 2012 \\
\text { North China }\end{array}$ & nd & 228.2 & 1933.9 & nd & 518.2 & $\mathrm{Nd}$ \\
\hline $\begin{array}{l}\text { Krolak, } 2000 \\
\text { Poland }\end{array}$ & 397.20 & 713.40 & 318.3 .30 & 12.50 & 470.90 & 36.10 \\
\hline
\end{tabular}

nd means concentrations were not investigated by other researchers

Vehicular emission which is due to aging of moving parts, releases heavy metals as $\mathrm{Zn}$ from tyres, $\mathrm{Cu}$ from brake linings and $\mathrm{Mn}$ from moving parts (Preciado and $\mathrm{Li}, 2006)$. However, anthropogenic sources of $\mathrm{Ni}$ and $\mathrm{Cd}$ in the atmosphere include stainless steel and other metal alloys which are also components of vehicles. Therefore, the high concentrations of the heavy metals in the current study are due to vehicular activities in the motor parks. Thus, these can increase the potential health effects such as (organ damage, blindness, deafness, breathing, sex problems and death) of occupants in the environment (US-EPA, 2005).

Conclusion: The concentrations of heavy metals (Mn, $\mathrm{Cu}, \mathrm{Zn}, \mathrm{Cd}, \mathrm{Pb}$ and $\mathrm{Ni}$ ) determined were found to be high and this was due to vehicular activities in the motor parks. Generally, the heavy metal concentrations decrease in the following order $\mathrm{Mn}>\mathrm{Zn}>\mathrm{Pb}>\mathrm{Ni}>\mathrm{Cu}>\mathrm{Cd}$ for all the three sites. $\mathrm{Mn}, \mathrm{Cu}$ and $\mathrm{Zn}$ were found to be higher in UI site compared to other two sites and was followed by Un site and each of the $\mathrm{Mn}, \mathrm{Cu}$ and $\mathrm{Zn}$ were found to be low at $\mathrm{Kw}$ site. $\mathrm{Ni}$ was found to be in the following decreased order at each site $\mathrm{Un}>\mathrm{Kw}>\mathrm{UI}$ while $\mathrm{Cd}$ was found to be in the following decreased order at each site: $\mathrm{Un}>\mathrm{UI}>\mathrm{Kw}$. However, $\mathrm{Pb}$ was found to be in reversed order for $\mathrm{Cd}$ and the order are $\mathrm{Kw}>\mathrm{UI}>\mathrm{Un}$. It is important that $\mathrm{Un}$ and Kw parks be paved while the vehicles that will ply these Universities sites should have good engine parts that are not old.

\section{REFERENCE}

Adekola, FA; Dosumu, OO (2001). Heavy metal determination in household dust from Ilorin City,

Nigeria. NISEB Journal 1 (3): 217 - 221.

Adriaenssens, E (2011). Analysis of heavy metals in ambient air. Spectroscopy Focus. Vlaamse Milieumaatschappij. Antwerp, Belgium. Accessed in 4 October. www.vmm.be

ASTM Standard D1739, 1998 (2010). Standard test method for collection and measurement of dustfall (Settleable particulate matter), ASTM International, West Conshohocken, PA, 2010, www.astm.org.

Beg, MAA;. Yousufzai, AHK; Mehmood, SN (1987). Air pollution in Karachi. Pak. J. Sci. Ind. Res. 30: 60-66.

Feng, S; Liu, H; Zhang, N; , X; Lin, H; Liu, Y. (2012). Contamination assessment of copper, lead, zinc and chromium in dust fall of Jinan, NE China. Environ. Earth Sci, 66: 1881-1886.

Ghosh, MK. (2014). An analysis of roadside dust fall in Bhilai-3 of durg district Chhattisgarh, Central 
India and its impact on human health. International J. of Res. in Environ. Sci. and Technology 4 (2): 54-60.

Khan, FU; Shakila, B; Ghori, GE; Ahmad, M. (2002). Air pollution in Peshawar (rate of dust fall). Pak. J. of Sci. and. Res., 45: 1-6.

Khan, SL; Asrar, ZM.; Gazala, S; Ghous, B..(2013). Chemical composition of traffic generated dust and its impact on human health with associated problems. Quetta. Sci. Technol. and Development, 32 (2): 154-164.

Krolak, E (2000). Heavy metals in falling dust in Eastern Mazowieckie Province. Polish J. of Environ. Studies, 9 (6): 517-522.

Malakootia, M; Ghiasseddin, M; Akbari, H; Allah N; Fard J (2013). Urban dust fall concentration and its properties in Kerman City. Iran. Health Scope, 1 (4): 194-200.

Matthews, A; Omoni, C; Kakulu, S (2012). Comparison of digestion methods for the determination of metal levels in soils in Itakpe, Kogi State, Nigeria. International J. of Pure and Applied Sci. Technol., 13 (2): 42-48.

Mohamed, AT; Mohamed, MA; Rabeiy, R; Ghandour, MA .(2013). A study of heavy metals in the dust fall around Assiu Fertilizer Plant. J. Environ. Protection, 4: 1488-1494.

Meena, M; Singh, MB; Chandrawat, U;. Rani A (2014). Seasonal variations and sources of heavy metals in free Fall dust in an industrial city of western India. Iranica J. of Energy and Environ., 5 (2): 160-166.

Mnisi, JS;. Moja, SJ. (2013). Seasonal variations in airborne heavy metals in Vanderbijlpark, South Africa. J. of Environ. Chem..and Ecotoxicol., 5 (9): 227-233.

Norela, S; Nurfatihah, M.Z; Maimon, A.; Ismail, BS. (2009): Wet deposition in the residential area of the Nilai Industrial Park in Negri Sembilan, Malaysia. World Appl. Sci. J., 7 (2): 70-179.

Preciado, HF; Li L.Y. (2006). Evaluation of metal loadings and bioavailability in air, water and soil along two highways of British Columbia, Canada. Water, Air and Soil Pollution, 172: 81108.

Tyagi, R; Tomar, N; TYagi, SR; Tyagi, SK (2014). Monitoring of particulate matter (SPM, RSPM AND DUST FALL) in ambient of Ghaziabad and Meerut area of national capital region, India.
International Journal of Research in Applied, Natural and Social sciences, 2(1): 2347-4580.

US-EPA, 2005. Particulate matter research.

Yahi, D; Ojo, NA; Ngulde, SI; Telta, AD; Dibila, HM; Sambo, N; Sanni, S; Sodipo, OA; Madziga, HA; Mbaya, YP; Simon, J;. Sandabe, UK. (2014). Economic implications of dust assaults on humans and animals exposed to environmental hazards due to air pollution in the dry belt zone of Nigeria. J. of Environ. Issues and Agricul. in Developing Countries, 6 (1): 2141-2731. 